\title{
Developing comics- based history learning media for the fifth grade in Pekanbaru City
}

\author{
Musnar Indra Daulay \\ Universitas Pahlawan, Riau - Indonesia, (musnarindra@yahoo.co.id)
}

\begin{abstract}
The purpose of this study was, therefore, to describe the processes and the results of developing the comic-based learning media on the subjects of Social Science-History for the fifth grade of primary school in Pekanbaru City. Research and Development (R\&D) and Instructional Systems Design (ISD) of ADDIE was used to develop the media. Validity, practicality, and effectiveness tests were used to qualify the developed product. The developed comic-based learning media was stated "valid" by two media experts (63.33\% and $90.83 \%$ respectively); by two material experts $(77.92 \%$ and $96.67 \%$ respectively); whilst media validation was $83.33 \%$ and materials' validation was $93.75 \%$. The results of One-to One, Small Group and Field Trials were 88,54\%, 93,23\%, and 92,20\% respectively. In conclusion, the research findings indicated that the developed comicbased learning media were stated valid and can be used in the intended context for the Fifth Grade of Primary Schools in Pekanbaru City.
\end{abstract}

Keywords: social science-history, comic, $R \mathcal{E} D$.

\section{Introduction}

Education is an important mission of the state in developing its nation (Budiningsih, 2005: 1). Nationally, education is defined as a conscious and planned effort to create an atmosphere of learning and learning process so that students can actively develop their potential to have spiritual power, self-control, personality, intelligence, noble character, and skills needed by him/her and the State (UU Sisdiknas No. 20/2003). Furthermore, Ali Moertopo in Widja (1989: 7) argues more specifically that education has a central idea, namely, the effort to develop human resources so that people can build themselves together with others in naturally civilizing and building up their community.

Varieties of kinds of subjects are given in schools and one of them is History. The purpose of studying this subject, History, is to satisfy the curiosity of past events, to know the description of the event, to know why it happened and how the end of the event, and the implications or impact of the event on other spheres of life (Tamburaka 1999: 5). This is in harmony with what is the goal of national education. That is, education and history is a unity, if national education is a way to realize the national ideals, then history is the foundation that strengthens the way in realizing the national ideals. Therefore, then history is one of the subjects that need to get attention from all parties, especially experts and observers of education problems. 
The understanding of history should be possessed by every person from an early age in order to know and understand the meaning of past events that can be used as a foundation of attitude in facing the reality in the present and determine the future. This means that History needs to be learned early on by every individual both formally and informally. The individual's relationship with society or nation requires the establishment of awareness of the importance of history to the problems of common life such as nationalism, unity, solidarity and national integrity. The realization of the ideals of a society or a nation is determined by the next generation who are able to understand the history of his/her society or nation.

As the impact of the implementation of the Integrated IPS on the basic education (SD and SMP), History is one part of the integration of IPS, in addition to other subjects such as Geography, Sociology and Economics. Unfortunately, until now the format and curriculum used still continue to experience improvements so that this one subject is still shaded by various problems. This is caused by many schools that implement IPS learning separately and of course this is not an easy matter when historical material should be taught integrated with other IPS materials, especially if the teacher's mindset so far still follows the old pattern that teaches IPS materials partially rather than integratively.

Based on interviews and observations that have been done on some students in class V SDN 097 Pekanbaru, the results obtained that sometimes they feel bored and can not capture the material being explained by the teacher. Teachers only introduce the name of the hero without telling the event in detail, so that learners tend to quickly forget the material that has been taught. The same thing was put forward by Elizarti, S.Pd grade V teacher who said that "Teachers rarely make their own learning media, it is because teachers are difficult to effectively and efficiently make media". These findings represent a portrait of learning atmosphere that occurs in almost all elementary schools in Pekanbaru city, which has an impact on the low interest and student learning outcomes.

Therefore, teachers should pay more attention to the implementation of learning history. The quality of the learning process needs to be improved so that the learning objectives can be achieved effectively and efficiently. Teachers need to strive for material to be conveyed and character values can be internalized in learning. Students need to be encouraged to give appreciation to events that occur in history, in this case, the media used to be one important factor in determining the success of achieving learning objectives. This is because the principle of good learning is if the learning process is able to develop the concept of generalization, and abstract material can be a clear and real thing, in this condition learning media have a contribution in improving student activity and motivation in learning. The media is certainly a medium that can stimulate the interest of students to learn and already known by the students.

To date, many media have been developed to facilitate the delivery of material by the teacher to the learners on historical material, such as audio-visual media or video and media images of heroes. However, sometimes the use of such media has both obstacles and weaknesses. Video media requires electronic equipment and electricity in its use, but it also requires special skills that teachers must have to be able to operate it. While the hero image media cannot deliver the historical message optimally. Based on this, the comic is an appropriate alternative to be used as a medium of learning history. The factors behind the researchers to conduct research entitled "developing social sciencehistory's comics-based learning media for the Fifth Grade of Primary School in Pekanbaru city.

\section{Method}

The research method used in this research was Research and Development (R \& D). The use of this method is to assist the researchers to develop social science-history's comics-based learning media for the Fifth Grade of Primary School in Pekanbaru city. This is in accordance with the opinion of Borg and Gall (1988) which states that research and development (research and development) is a research 
method used to develop or validate the products used in education and learning. The author seeks to develop a learning medium. For that, validation of the media is required. Furthermore, the procedures in this development research apply the ADDIE procedure. This model consists of five main stages, namely, Analysis, Design, Development, Implementation, and Evaluation or shortened ADDIE (Personal, 2011: 125).

The product of this media was validated by the experts.There were two experts who validated it, the media experts and material experts. The level of media validity is known through the results of the analysis of experimental activities carried out through two stages: (1) Expert test of learning media and subject matter experts. This activity is carried out to review the initial product and provide input for improvement; and (2) Questionnaire response student. This activity is conducted to find out how much children enjoy learning with comic media. In this development research, the subject of the quality assessment of comic media on learning IPS History class IV primary school consists of three media experts and materials experts. Comic media products that have passed the revision stage, tested in class V SDN 097 Pekanbaru. The author delivered the learning materials while applying the comic media in the learning process.

The instrument used was a questionnaire used to get an expert's assessment of the quality of the comic media. The quality of learning media is reviewed from several aspects, namely material suitability, media visualization, conformity with the principles of media development, feasibility and presentation of competencies. These aspects are interpreted into indicators and the researcher continued further development. The researcher developed a questionnaire of research using seven questionnaires in data collection, which is a media expert questionnaire, a material expert questionnaire, a media expert questionnaire from a teacher, a teacher's expert questionnaire, a fourstudent test questionnaire, a questionnaire of 8 students, and a student response class $\mathrm{V}$.

Data analysis is done to see the value of each aspect or descriptor in the questionnaire. Data were obtained from questionnaires given to media experts, material experts, and student responses. The collected data is analyzed by calculating the average score obtained. Score analysis used is descriptive analysis. The data obtained are quantitative and qualitative. Quantitative data are numbers obtained from a questionnaire of product development assessment and student response questionnaires that are arranged on a Likert scale (graded scale) and Guttman scale. Qualitative data in the form of responses, criticisms and suggestions set forth in the questionnaire. The resulting data relates to the suitability or suitability of the mining product made.

\section{Results and Discussion}

Analysis

The analysis in this study was conducted on the analysis of potential, problem, literature review, competence, instructional objectives, materials and development of learners. From the results of the analysis obtained the following data:

a) The analysis of potential, almost all elementary school children like to read comics as a means of entertainment. Children will more easily remember the characters from the comics they see. Empirically students tend to like picture books, colourful and visualized in both realistic and cartoon forms. For example, in Japan, in this country, the comic is no longer a foreign object used as a medium of learning. In fact, some school books in Japan are published in comic form. In fact, the comic became a very effective learning media and very interested students with pictures and how to speak straightforward.

b) The problem/needs analysis is done by interviewing the speakers namely, Elizarti.S.Pd, the fifth classsroom teacher SDN 097 Pekanbaru about the use of learning media. The results of interviews indicated that the teachers rarely make their own learning media, it is because teachers are difficult to make learning media effectively and efficiently. 
c) The analysis of literature review, based on the potential and existing problems researchers try to find a solution. The solution is based on the literature review conducted by the researcher. Furthermore, based on the potential and the problem, the researchers developed a comic learning media. The development refers to the expert opinion of Sudjana and Rivai who convey that the learning media can improve student learning outcomes.

d) The analysis of SK-KD, researchers analyze the existing competence in the object material that will be developed through the scope of learning and SK-KD.

e) The instructional analysis, instructional analysis in media development is done by describing and developing core competencies and basic competencies into the indicators that must be achieved.

f) The analysis of the characteristics of students, Piaget's theory of child development ability delivered that there are stages of development of children's ability in learning. According to him, elementary school children (8-11 years old) are still in concrete operation phase, so children need concrete objects to translate the concept they have. The use of media in learning in this period is very important because at this time students are still thinking concretely, have not been able to think abstract. The media will help

\section{Design}

the message delivered by the teacher to be more easily accepted by students.

In the design stage, the design concepts of the comic media consist of seven steps: 1) story ideas, 2) determining the character, 3) determining the theme, 4) arranging the setting, 5) arranging the story frame, 6) linking the material with the story, and 7) construct a story frame.

\section{Develop}

a. The develop stage's steps

The steps taken in the development and production process consists of several stages as follows:

1) Drawing and defining the main character in the comic,

2) Make the entire comic book according to the story frame using HVS and pen instrument medium, to proceed with the coloring process,

3) Incorporate conversation in comic story

4) Printing comics,

5) Sharing the comic to the students, it is enabled to make it easier for everyone to read and study the comis.

b. Assessment of Development

Assessment is done by way of validating media and materials, from the assessment results obtained data as follows:

Table 1: Result of the First Media Experts' Judgments/Validations

\begin{tabular}{clccc}
\hline No & \multicolumn{1}{c}{ Aspects of Assessment } & Mean Scores & Category & Percentage \\
\hline $\mathbf{1}$ & Indicators of Material conformity & 13 & Enough & $65,00 \%$ \\
\hline $\mathbf{2}$ & Media Visualization & 24 & Enough & $60,00 \%$ \\
\hline $\mathbf{3}$ & Conformity with the principles of media development & 26 & Enough & $65,00 \%$ \\
\hline
\end{tabular}

Table 2: Results of Second Media Validation

\begin{tabular}{llccc}
\hline No & \multicolumn{1}{c}{ Aspects of Assessment } & Mean & Category & Percentage \\
& & Scores & & \\
$\mathbf{1}$ & Indicators of Material conformity & 18 & Very good & $90,00 \%$ \\
$\mathbf{2}$ & Media Visualization & 37 & Very good & $92,50 \%$ \\
$\mathbf{3}$ & Conformity with the principles of media development & 36 & Very good & $90,00 \%$ \\
\hline
\end{tabular}


Table 3: Results of First Expert's Validation of Materials

\begin{tabular}{llccc}
\hline No & \multicolumn{1}{c}{ Aspects of Assessment } & $\begin{array}{c}\text { Mean } \\
\text { Scores }\end{array}$ & Category & Percentage \\
& & 9 & Enough & $60,00 \%$ \\
$\mathbf{1}$ & Indicators of conformity & 15 & Good & $75,00 \%$ \\
$\mathbf{2}$ & Feasibility indicators & 9 & Very good & $90,00 \%$ \\
$\mathbf{3}$ & Presentation Indicators & 26 & Very good & $86,67 \%$ \\
\hline
\end{tabular}

Table 4: Results of Second Material Expert's Validation

\begin{tabular}{llccc}
\hline No & \multicolumn{1}{c}{ Aspects of Assessment } & Mean & Category & Percentage \\
& & Scores & & \\
$\mathbf{1}$ & Indicators of conformity & 15 & Very good & $100,00 \%$ \\
$\mathbf{2}$ & Feasibility indicators & 18 & Very good & $90,00 \%$ \\
$\mathbf{3}$ & Presentation Indicators & 10 & Very good & $100,00 \%$ \\
$\mathbf{4}$ & Competency indicators & 29 & Very good & $96,67 \%$ \\
\hline
\end{tabular}

Table 5: Results of Media Master Expert's Validation

\begin{tabular}{llccc}
\hline No & \multicolumn{1}{c}{ Aspects of Assessment } & Mean & Category & Percentage \\
& & Scores & & \\
$\mathbf{1}$ & Indicators of Material conformity & 17 & Very good & $85,00 \%$ \\
$\mathbf{2}$ & Media Visualization & 32 & Good & $80,00 \%$ \\
$\mathbf{3}$ & Conformity with the principles of media development & 34 & Very good & $85,00 \%$ \\
\hline
\end{tabular}

Table 6: Expert Results of Master Material's Expert

\begin{tabular}{llccc}
\hline No & \multicolumn{1}{c}{ Aspects of Assessment } & Mean & Category & Percentage \\
& & Scores & & \\
$\mathbf{1}$ & Indicators of conformity & 14 & Very good & $93,33 \%$ \\
$\mathbf{2}$ & Feasibility indicators & 19 & Very good & $95,00 \%$ \\
$\mathbf{3}$ & Presentation Indicators & 9 & Very good & $90,00 \%$ \\
$\mathbf{4}$ & Competency indicators & 29 & Very good & $96,67 \%$ \\
\hline
\end{tabular}

\section{Implementation}

After the comic media stated feasible as a medium of learning. The next step was to apply the media. Implementation was done in three stages, namely small group 4 students, group of 8 students, and application in class V SDN 097 Pekanbaru. The results indicated that the comic-based learning media provides positive reaction to the students' learning satisfactions. The followings were the students' responses to the the comicbased learning media.

Table 7: Results of One-to-OneTrial (4 Students)

\begin{tabular}{clccc}
\hline No & \multicolumn{1}{c}{ Aspect of Assessment } & Mean score & Category & Percentage \\
1. & Ease of Understanding & 3 & Very good & $100,00 \%$ \\
2. & Learning Independence & 1,5 & Very good & $87,50 \%$ \\
3. & Activity in Learning & 3,25 & Very good & $87,50 \%$ \\
4. & Interest in comics & 2,25 & Good & $75,00 \%$ \\
5. & Comic presentation & 3,5 & Very good & $87,50 \%$ \\
6. & The use of comics & 3,75 & Very good & $93,75 \%$ \\
\hline
\end{tabular}


Table 8 Results of Small Group Trial (8 Students)

\begin{tabular}{clccc}
\hline No. & \multicolumn{1}{c}{ Aspect of Assessment } & Mean score & Category & Percentage \\
1. & Ease of Understanding & 3 & Very good & $100,00 \%$ \\
2. & Learning Independence & 1,75 & Very good & $87,50 \%$ \\
3. & Activity in Learning & 3,62 & Very good & $90,63 \%$ \\
4. & Interest in comics & 2,62 & Very good & $87,50 \%$ \\
5. & Comic presentation & 4 & Very good & $100,00 \%$ \\
6. & The use of comics & 3,75 & Very good & $93,75 \%$ \\
\hline
\end{tabular}

Table 9: Results of Field Trial (Fifth Grade Students of SDN 097 Pekanbaru

\begin{tabular}{clccc}
\hline No. & \multicolumn{1}{c}{ Aspect of Assessment } & Mean score & Category & Percentage \\
1. & Ease of Understanding & 2,85 & Very good & $95,10 \%$ \\
2. & Learning Independence & 1,79 & Very good & $89,71 \%$ \\
3. & Activity in Learning & 3,7 & Very good & $92,65 \%$ \\
4. & Interest in comics & 2,82 & Very good & $94,12 \%$ \\
5. & Comic presentation & 3,59 & Very good & $89,71 \%$ \\
6. & The use of comics & 3,68 & Very good & $91,91 \%$ \\
\hline
\end{tabular}

\section{Evaluation}

Evaluation is used to improve the product, the evaluation is based on the overall suggestion from the media and material experts, as well as the result of the student's response. Furthermore, the comic media is declared excellent to be a learning medium, so that no suggestion of media improvement is obtained.

\section{Discussion}

The developed media in this research is comic media, this media is developed based on research and development or research and development ( $R$ \& D) step with the model of DDIE. (analysis, design, development, implementation, evaluation). Comic media developed based on the analysis of conformity with the subjects. Furthermore, based on the standard competence and basic competence. And analyzed in accordance with indicators developed from the basic competencies of each subject. used researchers to design the design of comics.

In the development, the media needs to be validated by the experts before it is tested to try to find out its feasibility. The validator consists of the instructional media experts and the material experts. Based on the assessment results by media experts and material experts carried out improvements on media developed. Once the media is validated and the media declared eligible to use in the learning process. Then the comic media was piloted in the elementary school to see the response of the students. This test was conducted in SDN 097 Pekanbaru.Pengujian conducted from small group test 4 students, followed by 8 students and one class test. Validation results with media experts, obtained data as follows: (1) In the validation I level of comic media idealization is $63.33 \%$. Therefore a second revision and validation are performed, and (2) on validation II the revised level of media comics has reached $90.83 \%$. So the comic media is feasible to use.

Expert material validation results, obtained data as follows: (1) on the validation of I level of comic media idealization is $77.92 \%$. Therefore a second revision and validation are performed, and (2) on validation II the revised media idealization rate reached $96.67 \%$. So that comic Integrative media is feasible to use. While the results of the validation of media experts from teachers obtained data where the level of idealization of comic media is $83.33 \%$. While the results of material validation from teachers obtained data where the level of the ideality of comic media is $93.75 \%$. 
The result of media comic experiment, done gradually from small group of 4 students, 8 students to student 1 class. From the result of student response obtained by quantitative data. The product tested to try to 4 students obtained the result of the average score of student's response equal to $88,54 \%$. The product was tested to 8 students obtained the result of the average score of student's response is $93,23 \%$. While the product tested to try to 34 students grade IV SDN 097 Pekanbaru obtained the result of the average student response rate of $92.20 \%$.

Based on the analysis that has been done, it can be said that the developed media has fulfilled the quality of a good media, which includes valid, practical, and effective. Thus, the learning media in the form of comics on the subject of social science IPS can be used in the learning process to facilitate the students in understanding the concept of historical material that tends to abstract.Kelebihan owned this media, among others, can accommodate the interests and tastes of reading students, because elementary school students prefer reading which gives rise to many images, this medium can also increase learning motivation in students who can be seen from the student's response when the teacher provides comic media while learning. In addition, this media can accommodate the level of thinking of students who still adapt to the concrete operational level, so that material or concepts that tend to be abstract can be made concrete and easy to learn by the students. Through the interview with headmaster obtained the opinion that the comic media is a very good innovation to bring the spirit of learning and appreciation against independence fighters. Therefore, comic media can be a learning medium that is applied in teaching and learning process.

\section{Conclusion}

Based on processes and results of the research and development of comic-based learning media that have been done on V grade elementary school student in Pekanbaru city, obtained data showing that comic media is suitable to be used. The data is obtained based on the validation of material and media experts and data from the responses or responses of the students. So it can be concluded in general that the comic media deserve to be used as an IPS learning media History in class V Primary School. The lesson has been categorized good comic because it has fulfilled three criteria, that is valid, practical, and effective.

\section{Acknowledgments}

Suggestions from this research are: (1) for teacher and school, learning media in this comic form can be considered as media or learning tool, (2) making of comic media need long time and need good physical and psychic condition so that it takes time management and good self-management so that media can be developed maximally, (3) for further researcher, hopefully, can become reference and input for media development in comic form, especially on History subject matter.

\section{References}

Abdul Majid. (2007). Perencanaan Pembelajaran. Bandung. PT Remaja Rosdakarya

Arikunto, Suharsimi. (2010). Manajemen Penelitian. Jakarta: RinekaCipta.

Arsyad, Azhar. (2013). Media Pembelajaran. Depok: PT Raja Grafindo Persada

Avrilliyanti, Herlina. Dkk. (2013). "Penerapan Media Komik Untuk Pembelajaran Fisika Model Kooperatif

Dengan Metode Diskusi Pada Siswa Smp Negeri 5 Surakarta Kelas Vii Tahun Ajaran 2011/2012 Materi

Gerak".Jurnal Pendidikan Fisika (2013) Vol.1 No.1 halaman 156.http:/leprints.uns.ac.id/14512/1/1790-3995-1SM.pdf

Bonnef, Marcel. Komik Indonesia. (1998). Jakarta: KPG.

Branch, RM, \& Kopcha. TJ. (2014). Model desain pembelajaran. Dalam Handbook penelitian tentang komunikasi pendidikan dan teknologi

Daryanto. (2013). Media Pembelajaran Perannya Sangat Penting Dalam Mencapai Tujuan Pembelajaran. Yogyakarta: Gava Media 
Departemen Pendidikan Nasional. (2003). Undang-Undang Sistem Pendidikan Nasional Nomor 20 Tahun 2003, Jakarta: Depdiknas.

Faried Wadjadi. (2004). Pengaruh Pemberian Bahan Belajar Terhadap Hasil Belajar pada Mata Kuliah Rangkaian Dasar Listrik (Suatu Studi di Jurusan Teknik Elektro UNJ). Jurnal Teknodik No. 15/VIII/Teknodik/Des/2004.

Femi Olivia. (2008). Gembira Belajar dengan Mind Mapping. Jakarta: PT Elex Media Komputindo

Gooch, Deanna L. (2012). Research, Development, and Validation of aSchool Leader's Resource Guide for The Fasilitation of Social MediaUse By School Staff. Manhattan, Kansas: Kansas State University.

Hobri. (2010). Metodologi Penelitian Pengembangan. Jember: Pena Salsabila.

Karli, Hilda dan Margaretha. (2003). Implementasi Kurikulum Berbasis Kompetensi I. Bandung: Bina Media Informasi

Listyani, Indriana Mei dan Widayati, Ani.2012. Pengembangan Komik sebagai Media Pembelajaran Akuntansi pada Kompetensi Dasar Persamaan Dasar Akuntansi untuk Siswa SMA Kelas XI.JurnalPendidikan Akuntansi Indonesia, Vol. X, No. 2, Tahun 2012.

Mulyasa, H. E. (2014). Pengembangan dan Implementasi Kurikulum 2013. Bandung: PT Remaja Rosdakarya.

NTV Sekai Banzuke (World"s Rank) (2013), Indonesia placed 2nd for the biggest ... translating manga were found by Gyllenfiel (2013:10) in her thesis

Nurgiyantoro. (2005). Teori Pengkajian Fiksi. Yogyakarta: GMUP

Pribadi, Benny A.( 2011). Model Desain Sistem Pembelajaran. Jakarta: Dian Rakyat.

Prina, F. (2004). Perbandingan Hasil Belajar antara Siswa yang Menggunakan Buku Paket dengan Siswa yang Menggunakan Buku Komik pada Konsep Sistem Hormon. Journal of Applied Sciences Research, 3(10):913920

Putra, Nusa. (2015). Research \& Development. Jakarta: Rajawali Pers.

Ravelo, L. C. (2013). The use of comic strips as a means of teaching history in the EFL class: Proposal of activities based on two historical comic strips adhering to the principles of CLIL. Latin American Journal of Content and Language Integrated Learning, 6 (1), 1-19. doi:10.5294/laclil.2013.6.1.1 eISSN 2322-9721.

Rusman. (2015). Pembelajaran Tematik Terpadu Teori Praktik dan Penilaian. Jakarta: PT Raja Grafindo Persada

Sebastien Molina, J. Gomez and J Ortuno, (2014). History Education under the New Educational Reform: New Wine in Old Bottles?. International Journal Of Historical Learning, Teaching And Research Vol 12.2. University Of Cumbria

Soegeng, A.Y. Ysh. (2006). Dasar-Dasar Penelitian. Semarang: IKIP PGRI Semarang Press.

Sones, William. (1944). The Comics and Instructional Method. American Sociological Association.

Sudjana, Naana dan Rivai, Ahmad. (2011). Media Pengajaran. Bandung: Sinar Baru Algensindo Offset

Sudjana, Nana. (2013). Tuntunan Penyusunan Karya Tulis Ilmiah. Bandung: Sinar Baru Algensindo Offset.

Sugiyono. (2006). Metode Penelitian Kuantitatif, Kualitatif dan RED. Bandung: alfabeta

Sukmadinata, Nana Syaodih. (2013). Metode Penelitian Pendidikan. Bandung: PT Remaja Rosdakarya.

Suryosubroto, B. (2009).Proses Belajar Mengajar di Sekolah. Jakarta: Rineka Cipta.

Undang-Undang Republik Indonesia Nomor 20 tahun 2003 tentang Sistem Pendidikan Nasional. Jakarta: PT. Rineka Cipta

Wahyuningsih, Ary Nur. (2011) "Pengembangan Media Komik Bergambar Materi Sistem Saraf Untuk Pembelajaran Yang Menggunakan Strategi Pq4r".Jurnal PP Volume 1, No. 2.http://journal.unnes.ac.id/nju/index.php/jpppasca/article/viewFile/1533/1709. Diakses pada tanggal 10 Oktober 2017, pukul 07.10

Waluyanto, H D. (2005). Komik sebagai Media Komunikasi Visual Pembelajaran. Jurnal Universitas Kristen Petra 7 (1): 44-55.

Widodo, Chomsin S. dan Jasmadi. (2008). Panduan Menyusun Bahan AjarBerbasis Kompetensi. Jakarta: PT Elex Media Kompetindo. 